Vol. 10(4), pp. 104-110, April, 2016

DOI: 10.5897/AJEST2015.1958

Article Number: EA3BA1258196

ISSN 1996-0786

Copyright (C) 2016

Author(s) retain the copyright of this article

http://www.academicjournals.org/AJEST
African Journal of Environmental Science and Technology

\title{
Spatial dynamic of mobile dunes, soil crusting and Yobe's bank retreat in the Niger's Lake Chad basin part: Cases of Issari and Bagara
}

\author{
Moussa Issaka Abdoulkader ${ }^{1,5 *}$, Somé Yélézouomin Stéphane Corentin ${ }^{2}$, Abdourhamane $^{2}$ \\ Touré Amadou ${ }^{3}$, Hassane Bouba ${ }^{3}$, Malam Abdou Moussa ${ }^{1}$, Mamadou Ibrahim ${ }^{1}$, Abba Bachir ${ }^{1}$, \\ Garba Zibo ${ }^{3}$ and Yacouba Hamma ${ }^{4}$ \\ ${ }^{1}$ University of Zinder, Niger. \\ ${ }^{2}$ University of Koudougou, Burkina Faso. \\ ${ }^{3}$ Laboratory of Geology, University Abdou Moumouni, Sciences and Technology Faculty, Niamey, Niger \\ ${ }^{4}$ International Institute for Water and Environmental Engineering (Foundation 2iE), Burkina Faso. \\ ${ }^{5}$ Research Unit of Environment Evaluation, University of Zinder, Niger.
}

Received 5 July, 2015; Accepted 19 January, 2016

\begin{abstract}
The process of desertification is accelerated in the northern part of Lake Chad basin since the early 1970. Those processes linked to the recurrent drought and a heavy human pressure induced a great environmental damages. So this study based on diachronic cartography (1957, 1975 and 2007) aimed to describe and quantify the degradation dynamics in the contrasting Niger's Lake Chad basin part. Thus significant environmental changes have been observed in this area from 1957 to 2007. Indeed in the Manga, the natural commodities and fields were threatened by mobile dunes making blocking with sand: the mobile dunes spread from $\sim 200$ ha in 1975 to 900 ha in 2007 while they had not watched in 1957. In the fluvio-deltaic area of Kadzell, the soil crusting and the Yobe River retreat remain the major damages. The crusting area has been multiplied by more than two while the lateral migration of the Yobe bank reached near of $3 \mathrm{~m} . \mathrm{yr}^{-1}$. This study highlights the key role of man in the process of degradation related to climate parameters
\end{abstract}

Key words: Lake Chad, degradation dynamics, soil crusting, dunes, human activities.

\section{INTRODUCTION}

The Lake Chad basin covers 2.5 million square kilometers and spreads on eight African countries. It concerns the life of 30 million peoples and the economic activities of the people around the lake rely on fishing, cattle breeding, agriculture and trade. Those activities remain traditional and largely dependent of climatic conditions. Indeed, since the early 1970 , the processes of desertification were accelerated in the Niger and largely

${ }^{*}$ Corresponding author. E-mail: Kader_geol@yahoo.fr. Tel: (00227)99322286.

Author(s) agree that this article remain permanently open access under the terms of the Creative Commons Attribution License 4.0 International License 


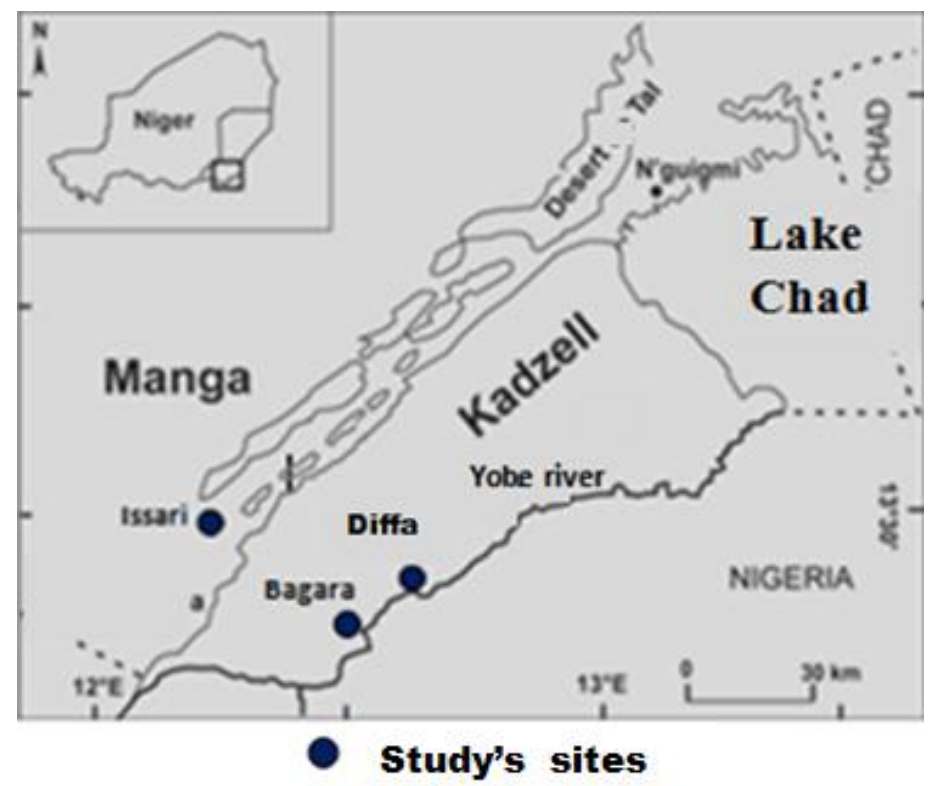

Figure 1. Localization of study's sites.

in the Sahel by a heavy human pressure and by recurrent drought which had induced the deaf of millions trees (Gado, 1992; Casenave and Valentin, 1992; Cornet, 2002; Tidjani, 2008; Lebel and Ali, 2009). The rapid population growth, largely observed in the Sahel, has increased food and firewood needs (Bielders et al., 2002, 2004; Tidjani, 2008; Boubé et al., 2011). This induced a progressive plant cover degradation linked to the extension of agricultural area and heavy breeding height (Moussa Issaka, 2014).

Besides the land degradation in the Sahel depends of geomorphology units and different degree of vulnerability to degradation was contingent to the lithology, vegetation cover and the vicinity of town (Couteron, 1997; Cissokho, 2011; Abdourhamane Touré, 2011; Moussa Issaka et al., 2014). In the Niger part, the geomorphology of the Lake Chad Basin is dominated by sandy plateaus (Manga), fluvio-deltaic area (Kadzell) and the Yobe River. Despite this contrast, the studies have been focused essentially on the Manga where mobile dunes make blocking with sand of pasturage, fields and other socio-economic commodity (Mainguet et al., 1979; Tidjani, 2008). The comprehension of the degradation dynamics in large contrasting basins like the Niger part of the Lake Chad basin is needed. This study aims to describe and quantify the environmental degradation dynamic in the various geomorphological units: Manga for dune dynamics, Kadzell for soil crusting and the Yobe River for collapse of banks.

\section{MATERIALS AND METHODS}

\section{Study area}

The study area comprises the Niger's Lake Chad basin part. The climate of the zone is sahelo-saharian with a mean annual rainfall ranging from 250 to $350 \mathrm{~mm}$. The Manga site (Issari: $13^{\circ} 42$ $\left.13^{\circ} 35 \mathrm{~N}, 12^{\circ} 13-12^{\circ} 21 \mathrm{E}\right)$ is dominated by shrub savanna and arborous savanna developed on sandy plateaus made of an ancient erg flattened by (ancient) runoff and (current) wind erosion (Durand, 1993). These plateaus slightly slope to the southeast towards the Kadzell (Durand, 1993).

Kadzell site is located in a fluvio-deltaic area (Bagara: 13०16$13^{\circ} 22 \mathrm{~N}, 12^{\circ} 37-12^{\circ} 42 \mathrm{E}$ ) and it is occupied by savanna developed in the Niger part of the Yobe alluvial plain (temporary tributary of the Lake Chad). It is made predominantly of an ancient erg flattened by winds, spread by the Komadugu Yobe and mixed with clayey fluvial contributions. The plain is bounded on the NE by a sandy beach barrier that separates it to the Manga plateau (Figure 1). Besides, Bagara is situated near the bank of the Yobe River. Yobe is a semipermanent river. Its flows generally occur from mid-July to stop in April for the period from 1962 to 1971, but stopped in March for the period starting from 1971 to 1985 and in February for the period from 1985 to 1993 (Moussa Issaka, 2014). In another way, October records near of $25 \%$ of the annual flow volume, September $22 \%$ and November $21 \%$ while the maximum daily flows recorded since the establishment of Bagara's station ranged from $25 \mathrm{~m}^{3} \cdot \mathrm{s}^{-1}$ to 84 $\mathrm{m}^{3} \cdot \mathrm{s}^{-1}$ (Moussa Issaka, 2014). This river spread the soil and imposed dynamic movement of the environment. This dynamic is analyzed at two meanders (B1, B2) around Bagara in relation with land use and climatic parameters.

\section{Landscape unit dynamics}

The strategy of the study is built on a diachronic cartography of landscape units between 1950 and 2007 in two sites Issari and Bagara (Figure 1). Thus aerial photographs of 1957 and 1975 completed with Landsat TM satellite images from 1975 and 2000, and Google Earth image of 2007 were used to produce land use maps for the periods 1957, 1975 and 2007 and to monitor the Yobe River. Thus panchromatic aerial photographs are scanned at 1200dpi for 1957 photographs and 300dpi for 1975 photographs with a resolution of 1 and $5 \mathrm{~m}$ respectively. These resolutions are sufficient to detect environmental changes. Then, scanned photographs were georeferenced in the Mercator projection system 
Table 1. Key of interpretation for aerial photographs (Source: CENATEL, 2007).

\begin{tabular}{lllll}
\hline Form & Gray tone & Texture & Structure & Identification \\
\hline Irregular & Moderately grey & Little bit smooth and granulated & Granulated and smooth & Savane arborée \\
Irregular & Enough dark gray & $\begin{array}{l}\text { Very few fairly smooth and } \\
\text { granulated }\end{array}$ & Granulated and smooth & Savannas \\
Irregular & Light gray & Very few granular & Homogeneous & Shrublands savannas \\
Regular & Enough clear gray & Smooth pretty to smooth & Homogeneous & Cultivated areas \\
Regular & Dark gray & Granulated and aligned in order & Very homogeneous & Plantation \\
Irregular & Very clear gray & Smooth & Homogeneous & Dune's and encrusted \\
Sinuous & Dark gray & Smooth & Homogeneous & Rivers \\
Irrégulière & Very clear gray & Granulated and group & Fairly homogeneous & Habitations \\
\hline
\end{tabular}

1957
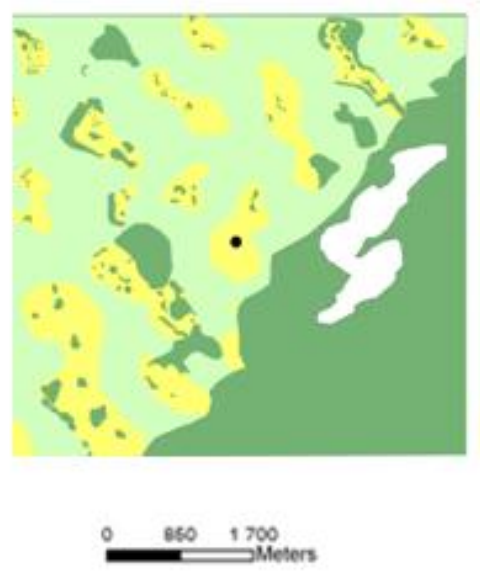

Total surface area $=9000$ ha $13^{\circ} 42^{\prime}-13^{\circ} 35^{\prime} \mathrm{N} ; 12^{\circ} 13^{\prime}-12^{\circ} 21^{\prime} \mathrm{E}$
1975
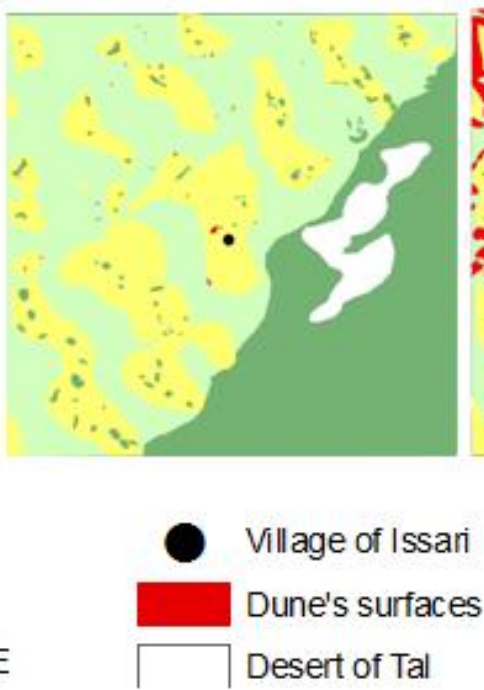

1 2007

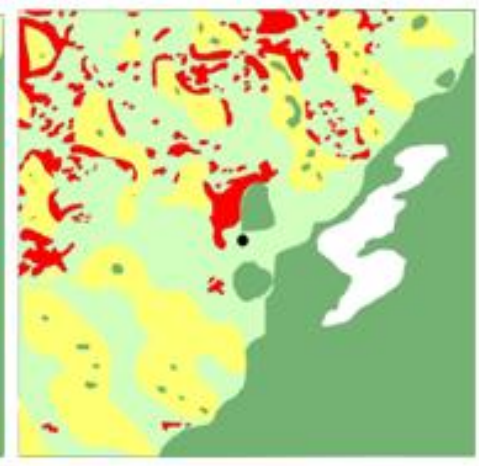

Cultivated areas

Savannas

Shrublands savannas

Figure 2. Land cover and land use of the site of Issari (Manga).

WGS_1984, UTM 33N by using the extension data analysis of Arc View processing software. Ten-minimal ground control points (GCPs) have been necessary to rectify each photo. The landscape unit mapping and classification is then done by using an aerial photographs key interpretation (Table 1). These keys consider agro-pastoral practices and landscape transformation in the Sahel (Diello, 2007). The results of the cartography have been checked during two ground-missions.

\section{RESULTS AND DISCUSSION}

\section{Landscape unit dynamics}

At Issari (Figures 2 and 3), the cultivated area have been increased from 3,555 ha (32\% of the mapped area) in 1957 to 4,222 ha (38\%) in 1975 before shifting down at 3222 ha (29\%) in 2007, where in Bagara (Figures 4 and $5)$, the increasing of cultivated area is regular from 850 ha $(11 \%$ of the mapped area) in 1957 , to 5,850 ha $(76 \%)$ in 1975 and 6,080 ha $(79 \%)$ at 2007 . In the zone, agriculture remains traditional, manual and it is usually done without fertilizers. In the context of food and firewood needs increasing linked to population growth, the consequence has been the extension of cultivated area. This cultivated area increasing has been reported in south- western Niger (Boubé et al., 2011; Abdourhamane Touré et al., 2010; Abdourhamane Touré, 2011) where 60,000 ha were subtracted annually in natural vegetation 


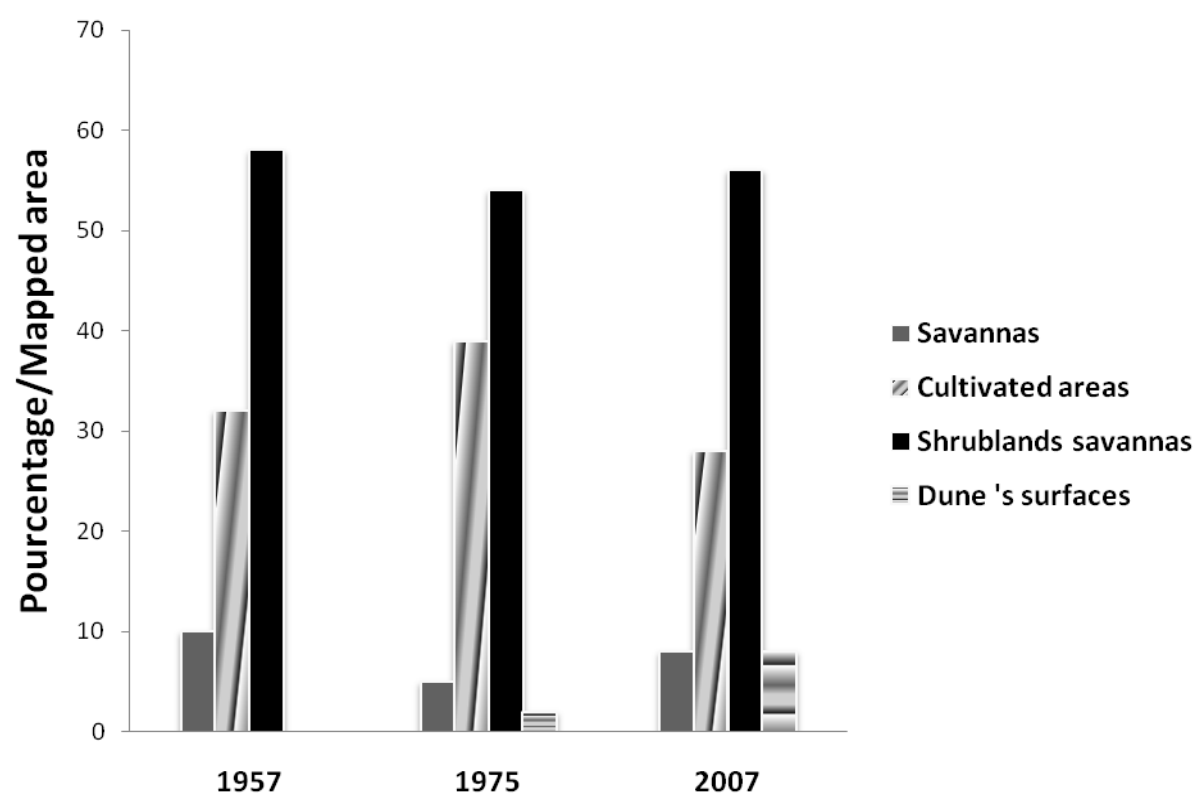

Figure 3. Land use dynamic at the site of Issari (Manga).

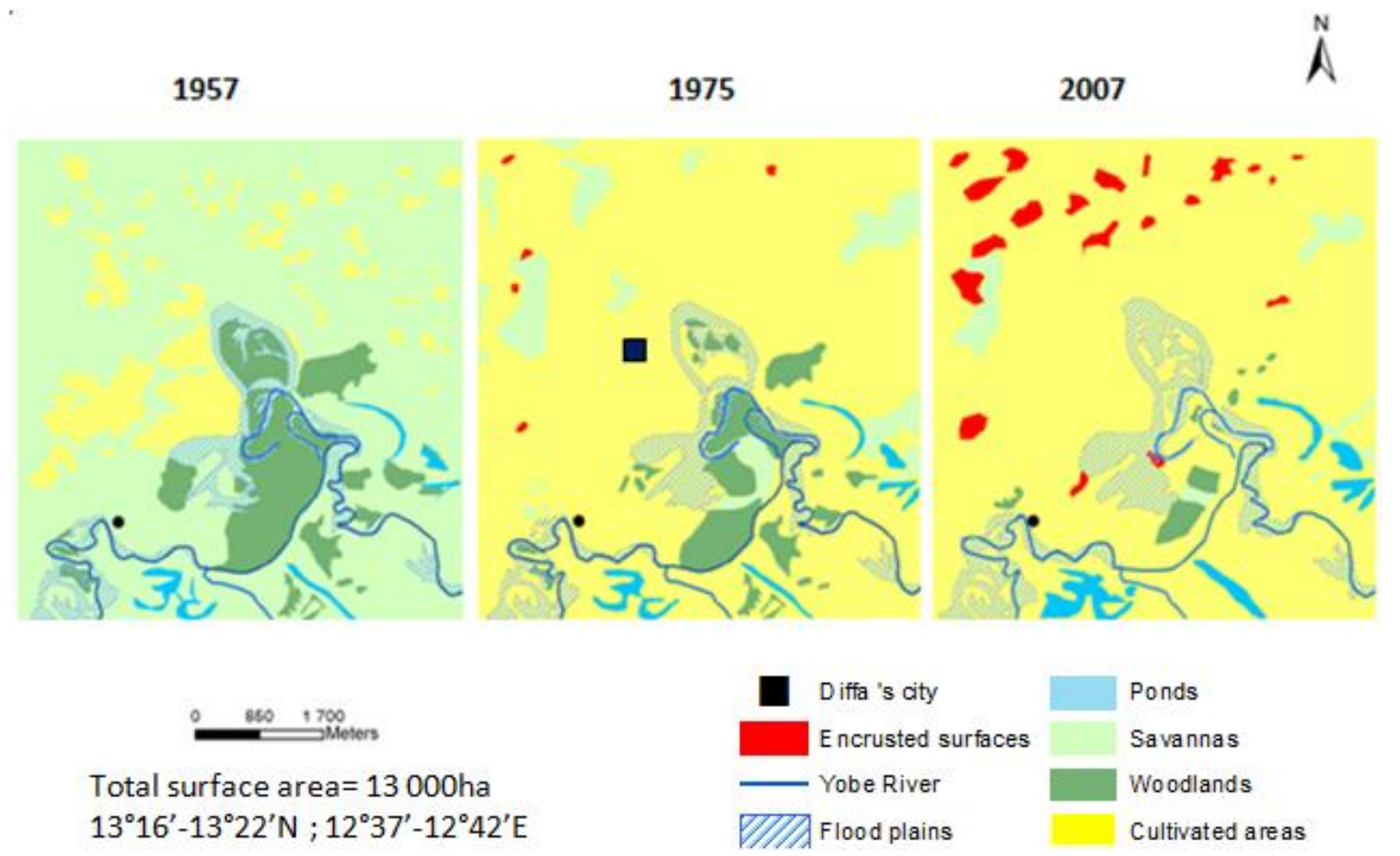

Figure 4. Land cover and land use at the site of Bagara (Kadzell).

for agriculture and uncontrolled deforestation (Ichaou, 1996). In the Burkina Faso, Diello (2007), observed the same trend and even under the Sudanese climate of Benin where the rainfall exceeds twice that of the central Sahel, Amoussou (2010) reported the increasing of the agricultural area.

At Issari, the declining in cultivated area between 1975 and 2007 occurred in favor of mobile dunes (Figure 2). These dunes appeared after 1957 occupied 222 ha (2\% of the mapped area) in 1975 (Figures 2 and 3). The 


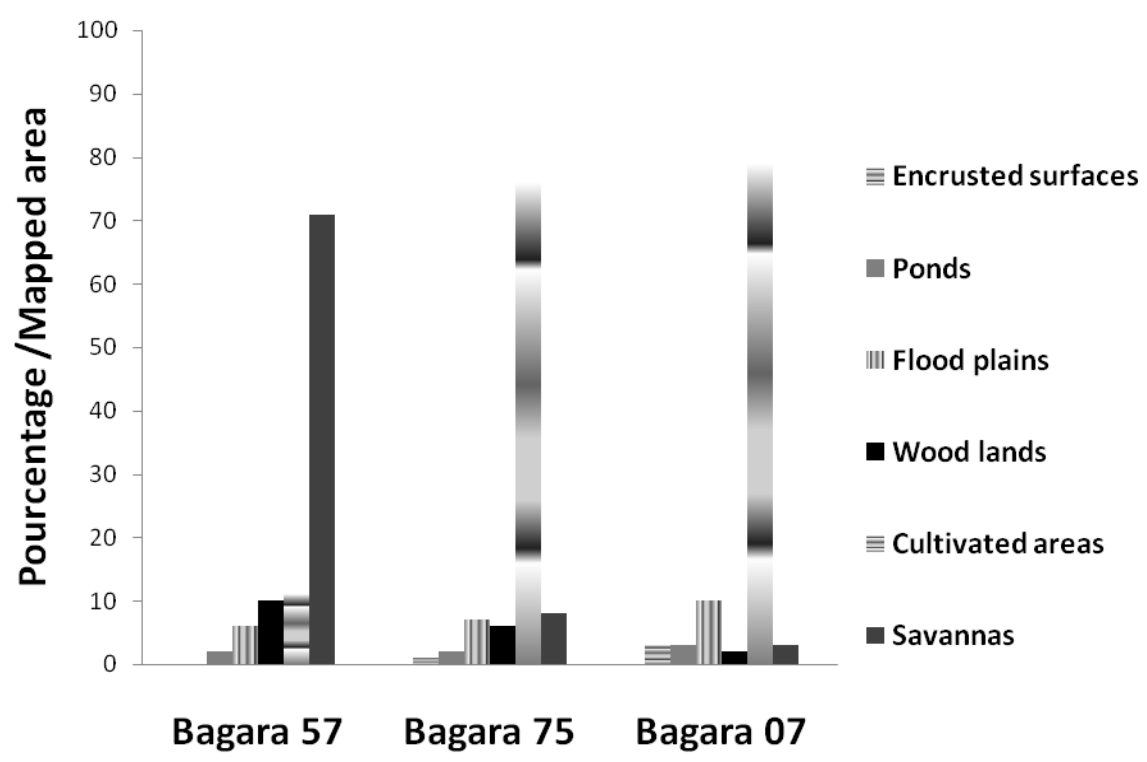

Figure 5. Land use dynamic at the site of Bagara (Kadzell).

mobile dunes occurrence was favored by the drought of the early 1970s and exacerbated by the deforestation and the cultivated area extension. The mobile dune appeared on the marginal soil of the sandy plateaus more sensitive to erosion when they have been cultivated (Cissokho, 2011) (Figure 2).

This increasing of dune's surface by human activities has been observed in the northern part of the Sahara in Algeria (Nedjraoui and Bedrani, 2008). From 1980 to 2005, in the southeastern Niger these dunes induced blocking with sand of more than $20 \%$ of the inter-dune basin which are the most productive soil in the area (Tidjani, 2008).

At Bagara, the appeared soil surface damage is erosion crust (Valentin and Bresson, 1992). These encrusted surfaces had the same dynamics as that of the dunes of Issari. Their expansion ranging from 76 ha to 230 ha respectively in 1957 and 2007 (Figures 4 and 5) is linked to the extension of cultivated area on marginal soil.

Indeed, in the southwestern Niger, the intensive cultivation of marginal soil which has less biomass productivity leads to less soil protected and great erosion rate followed by erosion crust extension (Abdourhamane Touré et al., 2010). Besides, the cultivation accelerated significantly nutrient's losses, reduces the physical and chemical soil fertility (Bielders et al., 2002). Also the pastoral charge $\left(0.40\right.$ heads. ha $\left.^{-1}\right)$ in 2009 (Moussa Issaka, 2014) is high than the balance charge in semiarid to arid zone estimated at 0.25 head.ha $^{-1}$ (Boukhobza 1982). Bagara is then overgrazed. Thus this overgrazing participated in the disappearance of the vegetation cover and increased the vulnerability of soil to erosion. Thus, in the Kadzell, the ultimate degradation is crusting unlike blocking with sand observed in Manga (Figures 2 and 4).
This difference of damage is essentially due to the geomorphology: Kadzell is an alluvial plain where the Manga is dominated by sandy plateaus. Nevertheless, the occurrence of the two damages highlights the important role of human pressure.

\section{Yobe river's bank dynamic}

The dynamics of the Yobe minor bed have been observed cartographically. Between 1957 and 1975, the lateral moving of Yobe minor bed was not very noticeable. On the contrary, between 1975 and 2007 the minor Yobe bed has evolved significantly. This evolution has been measured for two meanders (B1 and B2) bordering Bagara (Figure 6). It was very important from 1975 to 2007. At the B1 meander, the retreat of banks reached $120 \mathrm{~m}$ eastwards towards Bagara while for the B2 meander it was $92 \mathrm{~m}$ westwards backwards Bagara. The movement of the bed is accompanied by high sinuosity of the watercourse. The B1 meander wavelength $\left(\lambda B 1_{1975}\right)$ was $396 \mathrm{~m}$ in 1975 while it is $349 \mathrm{~m}$ in $2007\left(\lambda B 1_{2007}\right)$. For the $B 2$, the same dynamic of bringing closer of the meander's banks was observed. B2 wavelength is increased from $1083 \mathrm{~m}$ in 1975 ( $\lambda$ B21975) to $934 \mathrm{~m}$ in 2007 (AB22007). The years 1957 to 1969 were mostly wet period, before the beginning of the drought in the early 1970's. But, the dynamics of the minor Yobe bed remaided stable between 1957 and 1975. The stability of the Yobe River's bank would have certainly been linked to the presence of savannas along its banks (Figure 4). Indeed, vegetation prevents embankment erosion. This has been particularly obvious in western Niger along the Boubon's kori (Mamadou, 


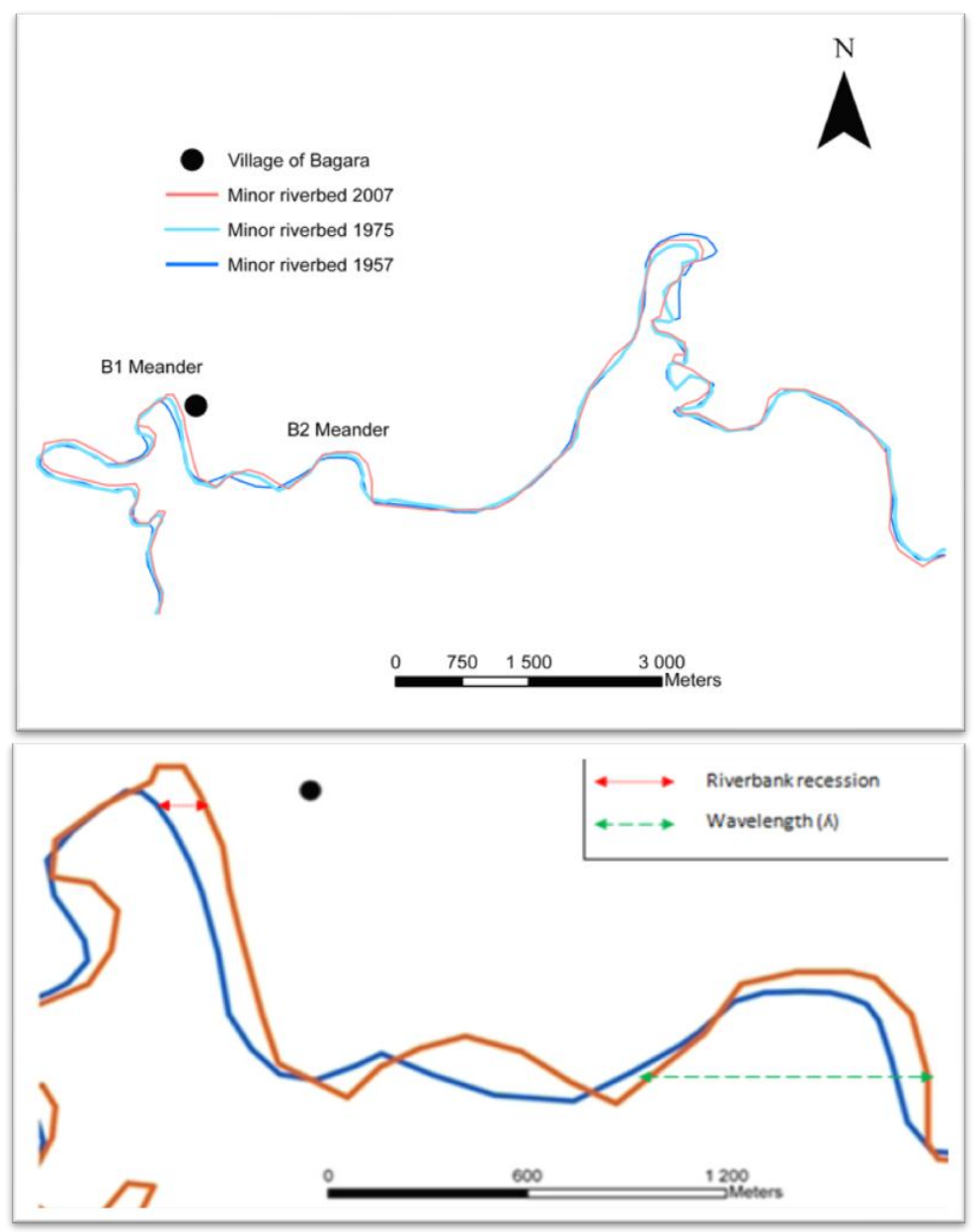

Figure 6. Polylines representing the minor riverbed of the Yobe river.

2012). This exoreic tributary feeding the Niger River has seen its eastern bank stabilized by hedges planted in 1985 , while its west bank, without hedges, is subjected to a lateral erosion of more than $2 \mathrm{~m}$ per year. Between 1975 and 2007, the migration of the minor Yobe bed was most pronounced exceeding $3 \mathrm{~m}$ per year. This occurred in the context of a rainfall crisis (Descroix et al., 2009a, b) and reducing Yobe flow (Moussa Issaka, 2014). It is expected that such conditions should reduce river bed erosion. However, the banks of the Yobe are under strong anthropogenic influence. Between 1975 and 2007, woodlands and savannas protecting its banks have lost $75 \%$ ( 600 ha) of their total area. Thus the speed of the Yobe riverbank migration is therefore probably linked to the intense clearing of its banks and the widespread of deforestation of its watershed by the exploitation of natural habitats (savannas and forests).

\section{Conclusion}

This analysis based on using of aerial photographs and satellite images allowed a description and a quantification of the degradation in the various geomorphological units of the Niger's Lake Chad Basin part. The environment has changed significantly between 1957 and 2007. It appears that the Manga environment is threatened by blocking with sand. Dune surfaces increased from 222 ha in 1975 to 888 ha in 2007. The alluvial plain (Kadzell) is threatened by soil crusting and Yobe River's bank retreat. Indeed, the encrusted area increased from 76ha in 1975 to 230 ha in 2007. The only river in the Niger's Lake Chad Basin part is under the collapse of the banks' threat and its migration. The displacement exceeds near of 3 $\mathrm{m} / \mathrm{yr}$ at the two meanders (B1 and B2) analyzed between 1975 and 2007.

\section{Conflict of Interests}

The authors have not declared any conflict of interests.

\section{ACKNOWLEDGMENTS}

The authors are highly indebted to the: University of 
Zinder, Niger, Abdou Moumouni University, Niamey, Niger, University of Koudougou, Burkina Faso, 2iE foundation, Ouagadougou, Burkina Faso.

\section{REFERENCES}

Abdourhamane Touré A (2011). Wind erosion on cultivated sandy environment in Niger: current and recent dynamics in conjunction with human pressure and climate change. PhD Thesis. University of Bourgogne, France. P 234.

Abdourhamane Touré A, Guillon R, Garba Z, Rajot JL, Petit C, Bichet V, Durand A, Sebag D (2010). Sahelian landscape evolution during the last six decades in the vicinity Niamey: from the bush Crusting disappearing to the soil. Pangea 47:35-40.

Amoussou E (2010). Variability of rainfall and hydro-sedimentary dynamics of complex watershed. Mono - river-lagoon - Ahémé Couffo (West Africa). PhD thesis. University of Bourgogne, France. P 313.

Bielders CL, Rajot JL, Amadou M (2002). Transport of nutrients and soil by wind in bush fallow land and cultivated fields traditionally managed in the Sahel. Geoderma 109:19-39.

Bielders CL, Rajot JR, Karlheinz M (2004). Wind erosion in the Niger Sahel: Influence of current agricultural practices and methods of struggle. Secheresse 15:19-32.

Boubé M, Ambouta JM, Saley Z, Ali M, Mahamane S, Zamah AM, Brice $S$ (2011). State of habitat degradation of the giraffe (Giraffa camelopardalis peralta Linnaeus, 1958) in Niger. Secheresse 22:5764.

Boukhobza M (1982). The Algerian agro -pastoralism, from colonial tribal order disorder. O.P.U, Algiers. P 458.

Casenave A, Valentin C (1992). A runoff capability classification system based on area features criteria in semi- arid areas of West Africa. J. Hydrol. 130:231-249.

Cissokho R (2011). Development of a vulnerability index to wind erosion from sattelitales image in the Groundnut Basin of Senegal Case Thies. Thesis. Montreal University. P 251.

Cornet A (2002). Desertification at the intersection of the environment: a problem for us. World Summit on Sustainable Development, which stakes? What contribution of scientists? Johannesburg. pp. 93-130.

Couteron P (1997). Contractions of vegetation and drought. Example northwest of Burkina Faso. In: JM of Herbs, Ambouta JMK, Peltier R, eds. Operation and Management of contracted forest ecosystems Sahel. Montrouge (France)

Descroix L, Mahé G, Lebel T, Favreau G, Galle S, Gautier E, Olivry JC, Albergel J, Amogu O, Cappelaere B, Dessouassi R, Diedhiou A, Le Breton E, Mamadou I, Sighomnou D (2009a). Spatio-Temporal variability of hydrological regimes around the boundaries Sahelian and Sudanian Between Areas of West Africa: A synthesis. J. Hydrol. 375(1-2):90-102.
Descroix L, Mamadou Moussa MA, Bashir A, Moussa I, Le Breton E (2009b). Status and proposed soils remediation on the Tondi Kiboro BV an experimental basis. International Symposium of Port-au-Prince (Haiti).

Diello P (2007). Interrelation Climate -Man- Environment in the Burkinabé Sahel: Impact on surface conditions and hydrological modeling . Geo- Hydro Science and Environment. University of Montpellier II. P 395.

Durand A (1993). Sedimentary record of climate dynamics at the upper Quaternary in the central Sahel (Niger and Chad). Thesis. University of Dijon. P 562.

Gado BA (1992). Traditional Concepts of droughts, famines and epidemics in the Sahel. Secheresse 3(4):243-250.

Ichaou A (1996). Ecological research applied to the management of forest ecosystems contracted trays Western Niger. Niamey. Orstom / Energy Project II. P 37.

Lebel T, Ali B (2009). Recent trends in the Central and Western Sahel rainfall diet (1990-2007). J. Hydrol. 375:52-64.

Mainguet M, Canon- Cossus L, Chemin MC (1979). Deterioration in the central regions of the Republic of Niger. Trav. Inst. Geogr. Reims. pp. 61-73.

Mamadou I (2012). Accelerated dynamics koris the Niamey region and its impact on the silting of the Niger River. Thesis. University Abdou Moumouni of Niamey and Paris I. P 290.

Moussa Issaka A (2014). Dynamics of erosion and landscape in the Niger part of the Lake Chad Basin. Thesis. University of Abdou Moumouni, Niger. P 180.

Moussa Issaka A, Somé Yélézouomin Stéphane C, Garba Z Abdourhamane Touré A, Yacouba H (2014). Erosion Response to Landscape Unit Changes in Eastern Niger: The Case of Bagara and Issari. Br. J. Appl. Sci. Technol. 4(21):2970-2984.

Nedjraoui D, Bedrani S (2008). Desertification in Algerian steppes: causes, impacts and control activities. Vertigo. Vol.8 No.1. Accessed March 5, 2013. URL: http://vertigo.revues.org/5375.

Tidjani AD (2008). Wind erosion in the Damagram East (southeastern Niger) parameterization, quantification and control methods. Thesis. Catholic University of Louvain. P 171.

Valentin C, Bresson LM (1992). Morphology, genesis and classification of surface crusts inloamy and sandy soils. Geoderma 55:225-245. 